\title{
The future of the Western world: the OECD and the Interfutures project
}

\author{
Jenny Andersson* \\ MaxPo Center for Coping with Instability in Advanced Market Societies, Sciences Po, 28 Rue des Saints Pères, 75005 \\ Paris, France. \\ ${ }^{\star}$ Corresponding author. E-mail: Jenny.Andersson@sciencespo.fr
}

\begin{abstract}
In 1975, the OECD created a research committee entitled 'Interfutures. Research project into the development of the advanced industrial societies in harmony with the developing world'. The purpose of Interfutures was to examine how the new tools of futures research could be put to use in order to shape strategies for dealing with a new phenomenon of 'interdependence', and to set out a 'long-term vision' of the Western world. This article argues that Interfutures was appointed in order to draft an alternative image of the future to two radical visions of the early 1970s. The first was the so-called New International Economic Order. The second was the 1972 Club of Rome report, The limits to growth. As a response to these two visions, Interfutures presented a vision of globalization as a process oriented around an expanding world market, piloted by Western interests and continued resource extraction.
\end{abstract}

Keywords: consultancy; Interfutures; limits; OECD; scenarios; world models

\section{Introduction}

In 1975, the Organisation for Economic Co-operation and Development (OECD) created a research committee entitled 'Interfutures. Research project into the development of the advanced industrial societies in harmony with the developing world'. ${ }^{1}$ The purpose of Interfutures was to examine how the new tools of futures research - in particular the scenario technique - could be put to use in order to shape strategies for dealing with a new phenomenon of 'interdependence', and to set out a 'long term vision of the major problems to which society will be confronted'.

Interdependence was a description of an emerging world order, still in the process of assuming its future shape. It was therefore, Interfutures argued, still capable of being influenced, but failing to steer interdependence in the right direction might result in a historic decline of the Western world. Interdependence portrayed a new 'world situation', in which a relatively stable world order had been replaced by the uncertainty resulting from the potential actions of more than 150 independent governments. ${ }^{3}$ The first two worlds were challenged by an emerging 'Third World'. The task of the Interfutures programme was to examine how conflicts of world order could be avoided, and how interdependence could be steered towards 'harmonious relationships' with the developing countries. ${ }^{4}$

A number of existing studies of the 1970s' notion of interdependence have situated it in the context of defensive Western responses to the 'shock of the global' unleashed by the Organization of

\footnotetext{
${ }^{1}$ All archival references are to the OECD archives, in particular the Interfutures folders, 1975-1979, MAS 80.9, ED 80-11, FUT (henceforth OECDA, Interfutures), a very large collection of material digitalized by the OECD.

${ }^{2}$ OECDA, Interfutures, Draft of background paper, proposed meeting of senior policy officials, 5 February 1978; Facing the future: mastering the probable and managing the unpredictable, Paris: OECD, pp. 4-5.

${ }^{3}$ OECDA, Interfutures, First draft of main issues paper, 19 May 1978.

${ }^{4}$ OECDA, Interfutures, Mission statement, Description of the research project.
} 
the Petroleum Exporting Countries (OPEC). These studies have pinpointed American attempts to meet challenges to its post-war hegemony through the gradual construction of a neoliberal vision of globalization, epitomized in the Washington consensus of the $1990 \mathrm{~s} .{ }^{5}$ The present article argues that interdependence was not a strictly American notion, but rather one that emerged from many sources, and only gradually gained meaning in the mid 1970s as an expression of a particular Western understanding of the need to manage and steer globalization towards visions of an expanding world economy, and that this happened as a response to other and clashing visions of globality.

Interfutures' reflection on the future did not stand alone, but was a response to more radical notions of globalization that emerged in the early 1970s. ${ }^{6}$ The OECD, an organization first created in the context of the Marshall Plan in 1948, emerged from the oil crisis convinced that a coming process of global market integration had to be consciously steered and managed. ${ }^{7}$ From the mid 1960s on, like many other Western organizations including the European Community, the OECD pioneered the notion of the Western world as a category threatened by globalization, and advocated far-reaching policy changes to Western welfare states. ${ }^{8}$

US scholars have highlighted the way in which the American administration used the idea of interdependence as a reaction to the Declaration of a New International Economic Order (NIEO), put forward by OPEC and the Group of 77 (G77), and voted for by the UN General Assembly in 1974. ${ }^{9}$ But in the context of the larger Western world represented by the OECD, the NIEO was one of two radical challenges to the post-war economic order: not only Third Worldism, but also the environmentalism present in the 1972 Club of Rome report, The limits to growth. ${ }^{10}$ The argument in the following pages suggests that it is necessary to understand the interplay between these two both radical arguments about global systems change - in order to understand the vision of globalization that Western countries would propose in the coming decades.

By examining the vision of interdependence put forward by the Interfutures project, I make three propositions. First, I show that it was through references and projections to the world future that the category of the Western world as the 'advanced industrial societies' (AIS) - a category in juxtaposition to the socialist economies and the 'developing world' - emerged. Forms of modelling, forecasts, and scenarios that permitted the depiction of a Western future in conflict with the futures of these other worlds were crucial here. Second, I argue that Interfutures pioneered methods of futures research, and particularly scenarios, as tools with which interdependence could be strategically managed, but not, importantly, planned. Third, I argue that the emerging historiography on neoliberalism has failed to connect the well-known arguments on 'structural problems' of Western planners, policy-makers and economists of the 1970s and 1980s with their desire to shape a long-term response to problems of globality. Meeting the twin challenges of a Third World exerting a competitive pressure on Western welfare states, on the one hand, and the environmentalist message of physical limits to growth, on the other, was crucial in reasserting the idea of Western growth among a much larger set of developmental

\footnotetext{
${ }^{5}$ Johanna Bockman, 'Socialist globalization against capitalist neocolonialism: the economic ideas behind the New International Economic Order', Humanity, 6, 1, 2015, pp. 109-28; Charles S. Maier, 'Malaise: the crisis of capitalism in the 1970s', in Niall Fergusson, Charles S. Maier, Erez Manela, and Daniel J. Sargent, eds., Shock of the global, Cambridge, MA: Harvard University Press, 2010, p. 32.

${ }^{6}$ Giovanni Garavini, After empires: European integration, decolonization, and the challenge from the Global South 19571986, Oxford: Oxford University Press, 2012.

${ }^{7}$ Matthieu Leimgruber and Mattias Schmelzer, eds., The OECD and the international political economy since 1948, Basingstoke: Palgrave MacMillan, 2017.

${ }^{8}$ Ravi Abdelal, Capital rules: the construction of global finance, Cambridge, MA: Harvard University Press, 2007; Vincent Gayon, 'L'OCDE au travail: contribution a une sociologie historique de la coopération économique international sur le chômage et l'emploi, 1970-2010', PhD thesis, Université Paris 1, Sorbonne, 2010; Anselm Doering-Manteuffel and Lutz Raphael, Nach dem Boom: Perspektiven auf die Zeitgeschichte seit 1970, Bonn: Vandenhoeck and Ruprecht, 2012.

${ }^{9}$ Declaration on the Establishment of a New International Economic Order, UN Assembly, Sixth Special Session, 1 May 1974.

${ }^{10}$ Donatella Meadows, et al., The limits to growth: first report of the Club of Rome, New York: Club of Rome, 1972.
} 
objectives. Overcoming physical limits put a premium, paradoxically, on what the Interfutures programme described as the non-physical limits to industrial growth, in terms of values and psychosocial reactions in Western populations. This is an important missing piece in the emerging historiography of neoliberalism as a non-linear, but contingent and gradual response to alternative and more radical visions of globality after $1973 .{ }^{11}$

The arguments in the coming pages run as follows. The first section of the article explains what the conspicuous formulation of 'harmonious relationships' meant and the rejection of the idea of global problems that it contained. The second section shows how the 'long term' as conjured by the Interfutures group became an argument for structural changes in the Western world. The final section discusses the role of scenarios as the method of choice for structuring this long term and managing interdependence.

\section{The world as system: the NIEO debate and the Limits to growth}

Recent literature on globality has greatly contributed to the historicization of the plurality of images of world interdependence after 1945 . $^{12}$ Some of the more interesting arguments from this literature have shown that notions of 'world system', 'world order', or, indeed, the use of the term 'global' were in fact vectors for radically different notions of globalization from the one that would come to dominate post-Cold War debates. This has made clear that the construction of a presentist neoliberal narrative of globalization from the 1980s onwards was a result of the exclusion of more radical visions of globality that had emerged from militant positions in fields as different as pacifism, Third Worldism, and environmentalism since $1945 .{ }^{13}$ In these visions, the notion of the future occupied a central space.

At the same time, the literature on globality has had the significant shortcoming of wanting to see all notions of globality and world order as part of one developing 'world consciousness', instead of situating notions of world, world order, system, or 'world future' at the heart of rival discourses on the future state of the world that emerged in the period from the mid 1960s to the late 1970s. This period is the one that Matthew Connelly refers to as 'future shock', with a term borrowed from a high-profile contemporary American book. ${ }^{14}$ Arguments such as Connelly's are emblematic of recent American historiography and its desire to depict American relations with the world, rather than world relations as such. In a strikingly similar way, a burgeoning literature on futures research, futurology, systems analysis, and prediction has also situated the origins of these approaches in a uniquely American context of so-called Cold War science. ${ }^{15}$ It has therefore not succeeded in distinguishing between the very different visions of the future of the world that these new approaches projected, and has failed to see that futures research was in fact a carrier of a key debate on the future of world order, at a specific moment in time when the long term' appeared as the relevant space of projection to world actors with profoundly different interests in the future stakes of the world. ${ }^{16}$

\footnotetext{
${ }^{11}$ The closest argument here is Garavini, After empires.

${ }^{12}$ Or Rosenboim, The emergence of globalism: visions of world order in Britain and the United States, 1939-1950, Princeton, NJ: Princeton University Press, 2017; Mark Mazower, Governing the world, New York, Penguin Books, 2012; Akira Iriye, Global community: the role of international organizations in the making of the contemporary world, Berkeley, CA: University of California Press, 2002; Elke Seefried, 'Globalized science: the 1970s futures field', Centaurus, 59, 2018, pp. 40-57; Casper Sylvest and Rens van Munster, eds., The politics of globality since 1945: assembling the planet, London: Routledge, 2016.

${ }^{13}$ Nils Gilman, 'The new economic order: a reintroduction', Humanity, 6, 2015, pp. 1-17; Bockman, 'Socialist globalization'.

${ }^{14}$ Matthew Connelly, 'Future shock: the end of the world as they knew it', in Fergusson, et al., Shock of the global, pp. 33751.

${ }^{15}$ See Mark Solovey and Hunter Cravens, Cold War social science: knowledge production, liberal democracy, and human nature, Amsterdam: Springer, 2012.

${ }^{16}$ Jenny Andersson, The future of the world: futurology, futurists, and the struggle for the Cold War imagination, Oxford: Oxford University Press, 2018. In this book, I introduced the argument that futures research was directly related to the
} 
The future shock described by Connelly was not driven by uniquely American political or epistemic developments. Futures research was, as is now well documented, an area with complex origins in cybernetic thinking, systems theory, and operations research, but also more humanist and philosophical foundations. It emerged as a new field of knowledge in the early $1960 \mathrm{~s} .{ }^{17}$ In the period from the mid 1960s on, futures research migrated, particularly in the form of new planning tools and models, into European welfare statist administrations, as new ways of managing a horizon that had expanded both spatially and temporally. At the same time, futures research became an area of interest to the large multinational Cold War corporations, most of which had an evident interest in surveying world futures, the evolution of commodity prices, and the risks of value change and revolution in commodity-producing countries. IBM, Kodak, Bell Laboratories, and Siemens, but also European public utilities such as the French SNCF or EDF, and of course the large oil corporations, all had corporate foresight departments by the early 1970s, and contributed actively to Western policy debates about strategic planning. ${ }^{18}$ Futures research thus circulated as a new set of strategy or decision tools between the corporate and the public sphere from the mid 1960s on, and as such it contained an appraisal of forms of decision based on corporate and market rationalities.

Several authors, including Seefried and myself, have seen futures research as a new form of global expertise, which carried visions of a shared, common, and interdependent world. ${ }^{19}$ Meanwhile, it is important to see that this new futuristic expertise was not simply composed of idealists believing in new versions of global solidarity, but also consisted of a new kind of world technocracy, armed with forecasts and scenarios of world development. Consultancy played a key role here as a new mode or genre of expertise, often drawing on economics, business strategy, and new anticipatory and forward-looking tools. Interfutures mobilized a forty-person team of consultants, and was directed by yet another consultant, the French systems analyst and engineer Jacques Lesourne. ${ }^{20}$ Owing to its organization with expert groups, the OECD championed consultancy. From the mid 1960s it understood its role to be a key provider of the so-called policy sciences and their new planning apparatus, including futures research, to member countries. $^{21}$

Futures research also launched a key debate about the world that would be the result of the ongoing trends of the present and would, in other words, constitute the 'long term'. In this context, the methods and technologies used to depict the coming world future that proliferated between 1967 and 1976 became something much more than mere narratives or representations of change; they became means of world intervention, tools for the actual shaping of future worlds and economic orders. They were highly contested. When the Club of Rome published its famous Limits to growth report in 1972, which pioneered the use of world modelling, it triggered what might be labelled the first genuine global controversy, a veritable war of models. The Limits report, with its neo-Malthusian message of the necessity to limit population growth in the developing countries and stop the pace of industrial growth within the next twenty years, was

struggle over world order, but did not examine how scenarios were in fact used in international organizations from the 1970s on.

${ }^{17}$ Ibid.; Seefried, 'Globalized science'.

${ }^{18}$ Royal-Dutch Shell was one of several corporate actors involved in the discussion of the long-term future of energy resources of the early European Community, which was itself a construction of several so-called prospectivistes, including Jean Monnet and Louis Armand.

${ }^{19}$ Seefried, 'Globalized science'; Egle Rindzeviciute, The power of systems: how policy sciences opened up the Cold War world, Ithaca, NY: Cornell University Press, 2016; Jenny Andersson and Egle Rindzeviciute, eds., The struggle for the longterm in transnational science and politics: forging the future, London: Routledge, 2015; Andersson, Future of the world.

${ }^{20}$ See Jacques Lesourne, 'L'exercice Interfuturs: réflexions méthodologiques', Futuribles, 26, 1977, pp. 20-38; Wolfgang Michalski, 'The OECD Interfutures project revisited 20 years later', in Jean Thépot, et al., eds., Décision, prospective, autoorganisation: mélanges en l'honneur de Jacques Lesourne, Paris: Dunod, 2000, pp. 318-31.

${ }^{21}$ See Patricia Clavin, 'Defining transnationalism', Contemporary European History, 14, 2005, pp. 421-39; Harvey Brooks, ed., Science, growth and society: a new perspective, Paris: OECD, 1971. 
met with devastating critique from different standpoints, both within and outside the Western world. ${ }^{22}$ In the years that followed the report, a number of rival models emerged. The most important of these was a report written by dependency theorists at the Fundación Bariloche in Argentina. The vision in Limits to growth of a world with finite boundaries put to the fore the question of who had the right to development. The Bariloche report proposed a new world economic system, organized around the concept of basic human needs, and around the prioritized right to development of the Third World in an essentially planned and directed world system. $^{23}$

In 1976, the Club of Rome, soliciting the Dutch social democrat, planner, and Nobel prize laureate Jan Tinbergen, reacted to the Bariloche message and its accusation of Western bias to its so-called 'world problematique'. The report written by Tinbergen, Reshaping the international economic order (the RIO model), was a shock to transatlantic relations, as it gave the "Third World' control of their own natural resources, and OPEC a new role in world financial institutions. ${ }^{24}$ It directly followed the NIEO Declaration of the Group of 77, which had met in Algiers in 1973 to demand a new share (25\%) of world manufacturing, hence rejecting the historic position of these countries as passive exporters of raw materials. In the following year, a UN Assembly in which the former colonies now held a majority, voted through the NIEO Declaration, which included the right to development and the sovereign use of natural resources. $^{25}$ Between 1972 and 1975, the UN produced at least three different models of the world system, including Tinbergen's RIO model, the so-called Mesarovic-Pestel model, and the 'UNmodel' created by the economist Vassilij Leontieff. ${ }^{26}$ An important element of these models was to break down the whole world model that had been the basis of the World II and World III models of the Club of Rome; instead, both the Mesarovic-Pestel model and the Leontieff model depicted future projections, where regional trends and tensions between world regions were crucial. This was an effect of demands made by Latin America and the Arab world, both of which understood the whole world image of Limits of growth as Western. ${ }^{27}$

The clash of models in the wake of the Limits report was not an example of a sudden future shock. It was rather the sign of the way that, by the 1970s, a number of competing discourses on the future of the post-war world order had come to maturity and reached a point of direct confrontation. This included American modernization theory, which had long outlasted its heyday in 1950s growth theory. ${ }^{28}$ By the early 1970s, modernization theory had produced an avatar in neoconservative conceptions of threatened American hegemony in a multipolar world epitomized in the Trilateral Commission, which advanced many of the same themes as the Interfutures group. ${ }^{29}$ The NIEO itself was a product of dependency theory, which was a direct

\footnotetext{
${ }^{22}$ Elodie Vieille Blanchard, 'Les limites à la croissance dans un monde global: modélisations, prospectives, réfutations', PhD thesis, Paris, EHESS, 2011; Elke Seefried, 'Rethinking progress: on the origin of the modern sustainability discourse, 1970-2000', Journal of Modern European History, 13, 3, 2015, pp. 377-400.

${ }^{23}$ Graciela Chichilnisky, et al., eds., The Bariloche report, Utrecht: Utrecht University Press, 1978; Sam Cole, Jay Gershuny, and Ian Miles, 'Scenarios of world development', Futures, 10, 1, 1978, pp. 3-20.

${ }^{24}$ Jan Tinbergen, Reshaping the international economic order: a report to the Club of Rome, New York: Club of Rome, 1976.

${ }^{25}$ Sibylle Duhautois, 'Un destin commun? Études sur le futur et formation d'une conscience globale 1945-1989', PhD thesis, Centre d'histoire de Sciences Po, 2017, ch. 4.

${ }^{26}$ See Rindzeviciute, Power of systems, pp. 137-9.

${ }^{27}$ Ismail Abdalla, Ibrahim Abdalla, Mahmoud Fadil, and Ali Nassar, Images of the Arab future, London: Francis Pinter, 1983, pp. 24-5.

${ }^{28}$ Nils Gilman, Mandarins of the future, Cambridge, MA: Harvard University Press, 2002; David Engerman, et al., eds., Staging growth: modernization, development, and the global Cold War, Boston, MA: University of Massachusetts Press, 2003; David Engerman and Corinna Unger, 'Introduction: towards a global history of modernization', Diplomatic History, 33, 3, 2009, pp. 375-85.

${ }^{29}$ Trilateral Commission, Towards a renovated international system, New York: New York University Press, 1977; Stephen Gill, American hegemony and the Trilateral Commission, Cambridge, MA: Harvard University Press, 2009; Phillip Golub, 'From the new international economic order to the G20', Third World Quarterly, 34, 6, 2013, pp. 1000-15.
} 
rejection of modernization theory. ${ }^{30}$ Third Worldism made two powerful claims: that the world 'system' led to the systematic depreciation of commodity prices in the global periphery, and that the Third World could shift the power balance of the post-war order by acting as a collective agent. The first oil crisis in the winter of 1974 was the apparent proof of this capacity. ${ }^{31}$

Both the NIEO and the Club of Rome were informed by systemic visions of the world. Systems theory was a profoundly complex thing, which not only portrayed rationalist accounts of a closed world but also allowed for the emergence of radical visions of how the world system could be redesigned in order to better suit human objectives. ${ }^{32}$ These visions of the world as a social system and manmade artefact allowed the notion of development to shift from the early post-war emphasis on aid to 1960s and 1970s debates on the systemic correlations between development in one part of the world and overdevelopment in another, and they therefore enabled radical visions of globality. By the mid 1970s, models of the world system postulated that commodity relationships, food resources, value systems, atmospheric pollution, and ocean warming co-existed in complicated world-encompassing chains. The Meadows team had discarded the first world model, the 'Predicament of mankind' model that had been designed for the Club of Rome by the Armenian-born former RAND systems theorist Hazan Ozbekhan. This model foresaw the only solution to the 'World Problem' as being a resetting of the entire system around human value change in the Western world. ${ }^{33}$ The World II model, produced by Jay Forrester at Massachusetts Institute of Technology (MIT), had originally been developed to forecast flows in warehouses in Boston harbour. It identified technological improvement and technology transfer as the only solution to the 'world problematique'. ${ }^{34}$ In the World III model, this was supplemented by the necessity to control world population. ${ }^{35}$

In response to the World III model, understood as projecting a 'whole' world, when in actual fact it projected Western interests onto the world, the UN Institute for Training and Research (UNITAR) in particular began experimenting with world models of regions. It was, in turn, in response to this breakdown of the 'whole world' idea into regions (particularly after a series of conferences on regional mobilization in the Arab world in 1971, 1972, and 1973) that scenarios of the evolution of so-called interdependence became the preferred depiction of the future of the West.

\section{Interdependence and the category of the Western world}

Both the NIEO and Limits to growth were full-frontal attacks on the post-war economic order as one dominated by Western resource extraction. While they could not come from more different positions - the Club of Rome was a group of Western industrialists and planners - they had in common the use of a global language, according to which solutions to world crisis could only be found by adopting a global perspective on resource use and problems of development. According to this global language, there were universal 'world problems' and 'common' challenges that

\footnotetext{
${ }^{30}$ See Mahbub Al Huqh, The poverty curtain: choices for the Third World, New York: Columbia University Press, 1976; Garavini, After empires, p. 29.

${ }^{31}$ Mark T. Berger, 'After the Third World? History, destiny and the fate of Third Worldism', Third World Quarterly, 25, 1, 2012, pp. 9-39; Arif Dirlik, 'Spectres of the Third World: global modernity and the end of the three worlds', Third World Quarterly, 25, 1, 2012, pp. 131-45; Garavini, After empires.

${ }^{32}$ Paul Edwards, The closed world, Cambridge, MA: MIT Press, 2010; Rindzeviciute, Power of systems.

${ }^{33}$ Hasan Ozbekhan, The predicament of mankind: a quest for a structured response to growing world-wide complexities and uncertainties. Original proposal to the Club of Rome. Paris: Club of Rome, 1970; Hasan Ozbekhan, A general theory of planning, Santa Barbara, CA: Systems Development Corporation, 1969.

${ }^{34}$ Elodie Vielle Blanchard, 'Technoscientific cornucopian futures versus doomsday futures', in Andersson and Rindzeviciute, Struggle for the long-term, pp. 92-115.

${ }^{35}$ Matthew Connelly, Fatal misconception: the struggle to control world population, Cambridge, MA: Harvard University Press, 2010.
} 
affected the whole of humanity. The fate of this humanity was intrinsically sealed in the vision of the future as the 'long term'. ${ }^{36}$

UNITAR and the Club of Rome were both part of a set of new spaces in the period from the late 1960s to the mid 1970s, which functioned as fora for the circulation of new forms of global knowledge, not least models and scenarios of world development. ${ }^{37}$ Egle Rindzeviciute shows that, in preparations for the International Institute for Applied Systems Analysis (created in 1972), the category of AIS referred to both the liberal and the socialist world - a neologism used to mark commonality and common challenges. ${ }^{38}$ However, global discourses changed profoundly from the optimistic tones of the late 1960s to the catastrophist notions of the early years of the 1970s. The return of rivalry between the blocs over commodity resources and privileged relationships with the Third World, and the rejection in the Third World itself of the idea of a 'whole world', changed the terms of world politics. The result was that ideas of a common category of AIS broke down, with whole world discourses being replaced by notions of tripartism or regional dominance, and, prevailingly, by a new understanding of the West.

By the mid 1970s, the term 'interdependence' had acquired a decisively Western meaning by which it was not the promise of a new world order but, rather, a threat to the one inherited from the nineteenth century. As shown by Nils Gilman and others, the notion of interdependence spelled the onset of a structured Western response to globalization. In reaction to visions of a shared and interconnected world, this response reasserted the existence of a separate and supreme set of interests as those of the AIS, which in the Interfutures report referred strictly to the Western world. In 1975, OPEC, adopting the language of the Algiers meeting and the NIEO Declaration, stated that 'interdependence requires a new approach to commodity pricing and the implementation of a New International Economic Order'. ${ }^{39}$ The US administration, under Kissinger, Ford, and Carter, reacted to the NIEO by reiterating bilateral trade agreements, by insisting on price mechanisms and free trade, and by structuring an alternative infrastructure of world governance to the UN system in the Group of 7 (G7). ${ }^{40}$ Interdependence was the marker in these contexts of the way in which the problems encountered by Western economies stagflation, rising oil prices, and long-term unemployment due to faltering growth rates - had their origins both in the inner workings of Western economies and in new conflicts over world order. ${ }^{41}$ From 1975 a new approach to the Third World was developed, in which Western regimes emphasized - through the G7, the European Community, and the OECD - the necessity of replacing the complex system of forecasts and negotiations of commodity prices with more qualitative assessments of shared points of interest. It is here that the work of the Interfutures group is particularly interesting.

In May 1975, the OECD ministerial meeting, at the request of the Japanese government and celebrating the ten-year anniversary of Japan's membership in the organization, decided on the creation of the Interfutures group. The need to structure a response to the NIEO by shaping collective action in the Western world was paramount: 'If these hundred could now act

\footnotetext{
${ }^{36}$ Jenny Andersson and Sibylle Duhautois, 'The future of mankind', in Sylvest and van Munster, Politics of globality, pp. 106-25.

${ }^{37}$ Egle Rindzeviciute, 'Purification and hybridisation of Soviet cybernetics: the politics of scientific governance in an authoritarian regime', Archiv fur Sozialgeschichte, 50, 2010, pp. 289-309.

${ }^{38}$ Rindzeviciute, Power of systems, pp. 129-35.

${ }^{39}$ Victor McFarland, 'The new international economic order, interdependence, and globalization', Humanity, 6, 1, 2015, p. 220.

${ }^{40}$ Daniel J. Sargent, 'North-South: the United States responds to the New International Economic Order', Humanity, 6, 1, 2015, pp. 201-16; Glenda Sluga, 'The transformation of international institutions: global shock as cultural shock', in Ferguson, et al., Shock of the global, pp. 223-37.

${ }^{41}$ Maier, 'Malaise', p. 32.
} 
as one .... ${ }^{42}$ Problems of interdependence were not 'world problems'; an early draft of Interfutures declared 'Their problems are not ours.' Rather, the Third World was exploiting weaknesses within Western nations, and exacerbating these by pushing through its own agenda. The Interfutures draft went on to argue that the trouble with notions of world problems was that they presumed shared interests on a universal value scale. Had not the Third World demonstrated that its historic resentment of colonial structures was now pushing it to pursue increasingly ideological and particularistic interests? The developing nations had a right to development and to basic human needs, but not the right to draw up a new version of the world industrial division of labour on a misguided idea that 'a conference could set down the new rules'. ${ }^{43}$ Indeed, Interfutures rejected the UN use of global modelling as biased against Western interests, and as presuming that there was any such thing as common or shared world problems. ${ }^{44}$ The draft argued that the concept of world problems should be confined to certain environmental problems of atmospheric pollution and environmental damage that transgressed national borders. These problems, in turn, could be solved, at the facile cost of $1 \%$ of GDP. ${ }^{45}$ The problem of a world industrial division of labour was also not a universal world problem, but a question of finding the long-term meeting points for the different interests of the developed and developing worlds. These meeting points, the final report would argue, lay in the intersection of the AIS acknowledging some of the developing nations as industrialized nations in their own right (such as Algeria, Brazil, and India, all of which experienced rapid industrialization in the early 1970s), and accepting these as new participants in an expanding world market, while other developing nations had to step back from the NIEO and recognize the advanced economies as the primary engines of the world economy. ${ }^{46}$

The original mandate for the Interfutures programme was to use the scenario method as a way of depicting changes in international relations, to predict desirable and undesirable consequences of the recent shake-up of world markets, and to find the points of interest convergence around which so-called 'harmonious relationships' could be created. Scenarios were thus a kind of methodological response to the 'determinism' of world models, and aimed explicitly at shaping interests within the expectation of a growing world market. The core of the research programme lay in the redrawing of an image of the world that could be a plausible alternative to the NIEO vision. According to the Interfutures group, the world consisted of three regions: the AIS, the less developed countries (LDCs), and the socialist economies. ${ }^{47}$ In addition, it had a possible fourth world or group, in those recently industrialized nations that no longer clearly belonged in the Third World. ${ }^{48}$ The point of the scenarios was to find strategies to reconcile long-term and shortterm interests, and to identify the common denominators for the AIS and the fourth group. 'How can a long term OECD interest in greater world equality be reconciled with its short term interests? How can the most advanced LDCs be integrated into world markets and their trade policies liberalized? Which policies should be adopted toward their industrialization process? ${ }^{49}$

\footnotetext{
${ }^{42}$ 'The imperatives of growth and cooperation', Ministerial meeting, OECD, 28 May 1975, quoted in Matthias Schmelzer, The hegemony of growth: the OECD and the making of the economic growth paradigm, Cambridge: Cambridge University Press, 2016, p. 317; OECDA, Interfutures, 'Midway through Interfutures: a first assessment of world problems'. See also Michalski, 'OECD Interfutures project', pp. 326, 330.

${ }^{43}$ OECDA, Interfutures, 'Midway through Interfutures'.

${ }^{44}$ OECDA, Interfutures, Newsletter, summary of the RIO report, July 1977; Summary of discussions, 13-14 October 1977; Summary of discussions, 19 January 1979.

${ }^{45}$ OECDA, Interfutures, 'Midway through Interfutures', p. 7.

${ }^{46}$ OECDA, Interfutures, Seminar on the use of global models, 26-27 January 1978; Background paper, meeting of the Steering Committee, 15 February 1978.

${ }^{47}$ OECDA, Interfutures, 'Searching for a new order of the world economy: resumé of the Interfutures conceptual framework regarding the Advanced Industrial Societies Rigidities'.

${ }^{48}$ Garavini, After empires, p. 207.

${ }^{49}$ OECDA, Interfutures, Midway through Interfutures, 'Cooperation with the LDCs'.
} 
Interdependence arose from the confrontation between the AIS and the LDCs, and from the emergence of new alliances between LDCs and the socialist economies. This resulted in a harshened competition over commodities, energy, and key minerals, in particular those that NIEO economists had singled out as objects of so-called cascading (for instance, copper, bauxite and aluminium, which were the basis of significant Western industries). ${ }^{50}$ At the same time, the Interfutures committee stated that these categories were themselves in flux, in such a way as to potentially break up both the Western world and the Third World itself. Within the LDCs was a fundamental dividing line between oil-exporting and oil-importing countries, as well as between countries whose industrialization process had taken off and were now harbouring a large industrial class, and countries that were essentially only locations for Western manufacturing (for instance, Bangladesh). The endurance of collective action capacity within the Third World could therefore be questioned, and the Interfutures group also signalled a significant risk of revolution in the oil-exporting countries once oil supplies dried up - unless these countries with their growing global proletariat could be integrated into a growing category of industrialized nations. It was in this manner, Interfutures argued, that the Western world had once successfully pacified the indigenous working class. ${ }^{51}$

The Interfutures group also depicted a Western world that was itself at the risk of cracking up. Narratives of European decline began long before OPEC, but the differences in response to monetary problems in 1973 and 1974 underlined the differences in economic regimes within western Europe, which therefore appeared as a remarkably unstable category. In response to what the programme labelled 'structural challenges', the Western world had adopted different, expansionist, and non-market-based social policy solutions that challenged the coherence of the West. In several countries, public sector growth was in the process of distorting market mechanisms, hence challenging the distinction between the AIS and the socialist economies. Some countries, such as the UK, had adopted stop-go monetarist policies worthy of a Third World country. The US, fearing the loss of its hegemonic position, was pursuing policies of independence, not interdependence'. ${ }^{52}$ Western nations had also developed profoundly different approaches to the Third World. Some of those confirmed previously existing colonial relationships as, for instance, in the Lomé Convention, in which France, the UK, and the Netherlands had negotiated bilateral long-term agreements on minerals. Others, such as Sweden, Norway, and the Netherlands, had supported the NIEO Declaration. The Interfutures group saw this as a dangerous situation, because it eroded the Western capacity for a united front towards a new collective actor, which, at least in 1973 and 1974, appeared to have a clearly discernible future strategy. ${ }^{53}$

Interfutures suggested that a concerted response to the Third World required the creation of a new long-term strategy, which would be capable of two things: first, to reassert the AIS as a collective actor with a coherent long-term interest vis-à-vis the LDCs, and second, to set out a shared set of policies for how the AIS would deal with structural challenges among themselves. In other words, the challenges of the NIEO were directly linked up with the idea of structural problems. If competitive advantage was to be restored with a Third World claiming a new share of industrial production, then public sector growth, rigidities in labour markets, and rising social costs were all problems that had to be addressed. This demanded, or so the Interfutures group suggested, a long-term perspective on the 'world situation' that set out the future benefits of liberalization in the present. ${ }^{54}$

\footnotetext{
${ }^{50}$ See UNITAR, Documents of the New International Economic Order, 1976-1979; Samir Amin, 'Self-reliance and the New International Economic Order', Monthly Review, 29, 3, 1977, pp. 1-21.

${ }^{51}$ OECDA, Interfutures, Midway through Interfutures, 'The international division of labour'.

${ }^{52} \mathrm{Ibid}$. See also Samuel Beroud, 'Positive adjustments: the emergence of supply side economics in the OECD and G7, 1970-1984', in Leimgruber and Schmeltzer, The OECD and the international political economy, p. 237.

${ }^{53}$ OECDA, Interfutures, Midway through Interfutures, 'The international division of labour'.

${ }^{54}$ OECDA, Interfutures, 'Resumé of the Interfutures conceptual framework regarding the Advanced Industrial Societies Rigidities'. See also D. Malkin and G. Sacco, 'Interfutures: the OECD research project', Futures, 9, 3, 1977, pp. 255-9.
} 


\section{Structural challenges and the problem of values}

The basis for a shared interest among the AIS was their mutual interest in retaining a dominant share of world industrial production and protecting indigenous labour. The precondition for this situation was the maintenance of stability in commodity prices and access to oil and core minerals; the core of the Interfutures programme thus consisted in a reflection on what kind of long-term strategy would procure stable access to these goods. What was needed, the group argued, was a new mechanism for stabilizing price movements, without actually displacing the market mechanism. 'The OECD should seek a mechanism that allows for avoiding erratic jumps in commodity prices, but maintains the long term determination of price through supply and demand. ${ }^{55}$ This led to a specific argument about the kind of steering methods that could ensure a long-term strategy, yet confirm the distinction between the Western economies and the planned economies.

The Interfutures programme argued that, in contrast to the socialist economies and the LDCs, the AIS were distinguished by the way in which they could not deal with future challenges through long-term planning, but had to resort to more open forms of long-term strategy, which included an extensive use of the market mechanism. This made them vulnerable to movements in commodity prices, particularly so in view of the fact that, from the late 1960s, the socialist bloc had reacted to the volatility in commodity markets by extending the use of long-term forecasting to the setting of prices, indicators, and terms of exchange on commodities with the 'Third World' ${ }^{56}$ This, to the Interfutures group, was an unacceptable extension of socialism to the world level. The allegation of world socialism was also extended to the NIEO, which Jacques Lesourne, who wrote the report, defined as a form of global communism based on the idea that UN planners could identify a new world goal. ${ }^{57}$ The NIEO was a vision of a 'world bureaucracy' that was not compatible with the market mechanism. ${ }^{58}$

What set the Western world apart, therefore, was the willingness to protect the market mechanism from both endogenous and global pressures, and find a 'new type of intervention mechanism which can foster cooperation', where forms of state intervention created conflict. ${ }^{59}$ Scenarios fulfilled exactly this role and, within the discussions of the Interfutures group, they became a preferred method both to the global modelling of the NIEO and, importantly, to the World models of the Club of Rome. It matters that the latter had originated within the OECD. As Mathias Schmelzer has shown, the OECD had taken an active interest in futures research and forecasting since 1967, when the OECD Science Policy Committee under Alexander King began examining what King referred to as 'problems of modern societies'. This phrase was a euphemism for a situation in which, a few crucial years before the oil crisis, growth and affluence appeared to have brought problems of large-scale societal rejection, value crisis, and increased demands for welfare and quality of life in Western economies. King himself was convinced that the post-war era of growth based on resource extraction was over, and that new forms of balanced growth, or alternative measures of development, had to be found in order to overcome environmental effects and large-scale societal rejection. ${ }^{60}$

In 1967, the Science Policy Committee published the report Technological forecasting in perspective, written by the consultant Eric Jantsch. This report presented the long-range

\footnotetext{
${ }^{55}$ OECDA, Interfutures, 'National and international institutions', p. 41.

${ }^{56}$ Michel Christian, 'Unctad and the regulation of international trade in the 1970s', in Michel Christian, Sandrine Kott and Ondrej Matejka, eds., Planning in Cold War Europe: competition, cooperatioon, circulation, (1950s-1970s), Berlin: De Gruyter Oldenbourg, 2018, pp. 285-315.

${ }^{57}$ The UN had a programme on world goals, and world planning was a key element in Tinbergen's RIO report. See Erwin Laszlo, Goals for mankind, New York: Club of Rome, 1977.

${ }^{58}$ OECDA, Interfutures, Seminar on the use of global models, 26-27 January 1978.

${ }^{59}$ OECDA, Interfutures, Main issues paper, September 1978, p. 40; Midway through Interfutures, 'The evolution of international relations', p. 45.

${ }^{60}$ Matthias Schmelzer, 'The crisis before the crisis: the problems of modern society and the OECD, 1968-74', European Review of History, 19 6, 2012, pp. 999-1020.
} 
forecasting that had developed particularly in the large military technical corporations of the Cold War: Lockheed, Kaiser Aluminum, and, in Europe, the Battelle Institute (its president, Ernst Thiemann, was an early member of the Club of Rome). As the world's biggest buyers of minerals, these corporations also figured extensively in the Interfutures report. ${ }^{61}$ Jantsch was knowledgeable of the way in which 'integrated forecasting' was used in the socialist economies from 1967 onwards as a form of total planning of economic, social, technological, and cultural change in communist society. ${ }^{62}$ He proposed that the OECD member states similarly needed to develop a forecasting ambition that could help set goals, identify relevant strategies, and plan for feedback loops, including value change and social reactions to economic and technological change. In addition, long-range forecasting could help shift the planning rationalities of the Western nations from that of the restricted nation space to the world level, while simultaneously extending the five- to ten-year horizon normally in use in conjectural planning to the 'long term' ${ }^{63}$

In 1968, King and Jantsch held a seminar on planning in the Rockefeller Foundation Center in Bellagio. The seminar was directly inspired by their proposal to create a separate planning initiative to deal with what was now labelled 'social crisis' and 'global crisis'. The Bellagio Declaration stated that the late 1960s were a time of 'planetary emergency', and that a common world future was threatened by social and ecological costs to growth. ${ }^{64}$ The meeting led to the creation of the Club of Rome, charged with examining the 'predicament of mankind' at the threshold of ecological and social disaster. ${ }^{65}$

As the Club of Rome published its report in 1972, including calls for zero growth and the substitution of growth with other values such as welfare, happiness, or quality of life, the Science Policy Committee increasingly came into conflict with the OECD economics and manpower departments. In 1972 and 1973, the economics department began to re-evaluate the forecasts of the Limits report. ${ }^{66}$ With the oil crisis and the ensuing stagflation crisis in 1973 and 1974, debates were increasingly dominated by monetary problems, oil prices, and employment. ${ }^{67}$ The Club of Rome was dismissed as 'prophetic seers' in missives from the economics department, and working papers rejected the Limits message with the argument that there was no inherent conflict between the values of growth and the environment. ${ }^{68}$ At the ministerial meeting in 1975, the statement reaffirmed what Schmelzer calls the hegemonic growth paradigm, by stressing that rising social expectations could only be managed by continued growth, and that governments had responsibility first and foremost for the pursuit of growth. The same ministerial meeting appointed the Interfutures group, which in other words has to be understood as having been created with the specific objective of creating a vision of the future that could refute the Limits report. ${ }^{69}$

Interfutures emphatically stated that there were no physical limits to growth. 'Most questions have nothing or very little to do with physical constraints to growth but seem to be much more related to political and social limits to growth. ${ }^{70}$ That this was the underlying assumption of the programme is also testified to by the writings and interviews of the programme director, the French economist Jacques Lesourne. On French television in 1981, a few years after the

\footnotetext{
${ }^{61}$ Eric Jantsch, Technological forecasting in perspective, Paris: OECD, 1967.

${ }^{62}$ Viteszlav Sommer, 'Forecasting the socialist future: prognostika in late socialist Czechoslovakia', in Andersson and Rindzeviciute, Struggle for the long-term, pp. 144-68.

${ }^{63}$ Jantsch, Technological forecasting in perspective.

${ }^{64}$ Schmelzer, Hegemony of growth, p. 252; Eric Jantsch, ed., Perspectives on planning: papers from the Bellagio conference, Paris: OECD, 1969.

${ }^{65}$ Matthias Schmelzer, 'Born in the corridors of the OECD: the forgotten origins of the Club of Rome, transnational networks, and the 1970s in global history', Journal of Global History, 12, 2017, pp. 26-48; Jantsch, Perspectives on planning; Aurelio Peccei, The chasm ahead, New York: Macmillan, 1969.

${ }^{66}$ Brooks, Science, growth, and society.

${ }^{67}$ Schmelzer, Hegemony of growth, pp. 268, 281.

${ }^{68}$ Ibid., p. 283.

${ }^{69}$ See ibid., pp. 284, 315. See also Michalski, 'OECD Interfutures project', p. 326.

${ }^{70}$ OECDA, Interfutures, Midway through Interfutures, 'Present perceptions of long term problems', p. 5.
} 
publication of the final report, Lesourne explained his own perspective on the future as a violent reaction to the impermissible determinism of the Limits to growth report. 'The future is blocked by a ton of concrete called "limits". The truth is that the problem of natural resources needs to be put in a completely different context. ${ }^{, 71}$ This different context included the end of states as possible social regulators, new social demands on behalf of countless individuals and groups in Western societies, the multipolarity of a post-Cold War world, and, indeed, a new world situation of interdependence. Lesourne's 1981 book, Les mille sentiers de l'avenir, described interdependence' in striking terms as a problem of rational control, which introduced new cut-off points between Western national governments and a new world 'system' of hundreds of unforeseeable actors. $^{72}$

Lesourne was the author of the Interfutures final report, working with a team of consultants that included the Japanese economist Yoshihiro Kogune, the American sociologist Daniel Bell, and the French planner Bernard Cazes. In the final report, the Interfutures committee explained that there were no reasons to think that there were limits to growth, because both the composition and the redistribution of growth and GDP would change in the future. What did pose limits to future growth, however, were the 'psychosocial reactions' and 'value crises' in the Western world: 'The economic and socio-political problems of the world seem more important than the physical problems.' This meant to Interfutures that the main problems for the future lay neither in an enduring confrontation with the Third World, nor in the limits posed by environmental exhaustion, but, rather, in the risk of a rejection of the market in the Western world, through 'the emergence of a new set of values: the concern with externalities and welfare, the questioning of profit. The market mechanism is poorly understood and the market is criticized. ${ }^{73}$ The main issue for the Western world resided in structural problems of ungovernability, value change, and increased social unrest. These problems, and in particular the 'values and attitudes of people' and 'social groups' who 'are not prepared for the problems with which they will be confronted as a result of the existence of the Third World', were the ones that posed internal constraints for growth. ${ }^{74}$ Caught between the demands for protection by domestic groups, who also questioned the legitimacy of growth, and a Third World bid for industrial shares, Western governments were faced with a situation of 'competing claims'. These somehow had to be reconciled, as did the long-term interest of ensuring harmonious relationships with the developing nations and the short-term interest of maintaining growth. 'Governments will have to create consistent long term policies capable of managing growth and social compromise. ${ }^{75}$

Scenarios based on the forecasting of specific economic, social, technological, and cultural factors here became the method of choice. The first years of the Interfutures programme were devoted to evaluating existing global models and rejecting them. From 1977 and 1978, the group concentrated on structural problems and on the possibility of writing a number of different scenarios in order to address them. In these scenarios, the question of values and the role of values as the main problem of 'manageability' and 'governability' of the AIS economies became the pivotal point. ${ }^{76}$ The value crisis and 'socio-cultural factors' were also singled out for separate study, at the specific request of Japan, and of the Toyota Foundation, which funded part of the Interfutures programme (other funders were the Ford Foundation and the German Marshall Fund). ${ }^{77}$ In 1967 and 1968, Japan had pioneered the use of technological forecasting, as part of a growing concern with the durability of the high-growth economy. Jantsch's 1967 report was

\footnotetext{
${ }^{71}$ Temps X, 'Jacques Lesourne et l'avenir', 29 November 1981, available at http://www.ina.fr/video/I11087636/jacqueslesourne-et-l-avenir-video.html (consulted 12 November 2018).

${ }^{72}$ Jacques Lesourne, Les mille sentiers de l'avenir, Paris: Segher, 1981, p. 18.

${ }^{73} \mathrm{OECDA}$, Interfutures, Midway through Interfutures, 'An assessment of world problems'.

${ }^{74}$ OECDA, Interfutures, Midway through Interfutures, 'Present perception of long term problems', p. 14.

${ }^{75}$ Ibid.

${ }^{76}$ OECDA, Interfutures, Summary of discussions, 13-14 October 1977.

${ }^{77}$ OECDA, Interfutures, Letter from the Japanese government to the Secretary General, 9 May 1975.
} 
immediately translated into Japanese. ${ }^{78}$ Saburo Okita, head of the Japanese Overseas Fund and leader of the Japanese OECD delegation, had a background in futures research as the former chair of the Japanese Futurological Society, and several other members of the Japanese OECD delegation had also emerged from the Futurological Society, including Kogune and Yoneji Masuda. The Society was directly linked to the Japanese Office of Technological Planning as a central overseer of Japan's industrialization process, and to the Institute for Information Society, in charge of planning the transition to post-industrialism. ${ }^{79}$

The Japanese were concerned with the value reactions to post-war growth rates that could be observed in the Western world. They drew the conclusion that Japan, with its extreme levels of industrialization in the post-war decades and anticipations of a leap into a post-industrial economy, ran a high risk of similar developments and that these could be detrimental to growth. ${ }^{80}$ The 'Japanese project', a draft written by the Toyota foundation, argued that a core purpose of futures research had to be to understand the causality between high-speed change and social rejection. ${ }^{81}$ The Toyota proposal argued that the Western welfare state had failed in providing general happiness. Rather, it had created a new structural contradiction between economic and technological development, on the one hand, and human satisfaction, on the other. The final report to Toyota was entitled 'Changing value patterns and their impact on economic structure' and argued that such structural conditions could be managed through scenarios. $^{82}$

Japan (represented by the same Okita, later foreign minister of Japan) was the third node of the Trilateral Commission, which introduced the theme of the 'ungovernability' of Western political systems. The notion of ungovernability stemmed from the French sociologist Michel Crozier's analysis of public bureaucracies. Crozier was the European representative on the Commission. In previous years, he had worked with the Paris-based Futuribles international group along with Bernard Cazes (and Lesourne, who, at the time of his appointment to Interfutures in 1975, was the director of Futuribles international). ${ }^{83}$ There were other overlaps between the Interfutures group and the Trilateral Commission: the American author on the Trilateral Commission was Zbiegnew Brzezinski, whose interest in futures research lead to the book Between two ages: America in the technetronic society (highly inspired by the Japanese notions of 'multichannel society' that had emerged from the Futurological Society). ${ }^{84}$ Daniel Bell, who was president until 1974 of the American Commission for the Year 2000, for which Brzezinski wrote papers, was hired as a consultant to Interfutures in 1975 . In 1972 and 1973 he travelled the world with his lecture 'The next twenty-five years'. The lecture included a citation that figured in the Interfutures report as well as in Lesourne's writings: 'Governments are too big for small problems. But governments are too small for big problems. 85

\footnotetext{
${ }^{78}$ Eric Jantsch, 'Technological forecasting in Japan: notes from a brief visit', Technological Forecasting and Social Change, 2 , 1970, pp. 325-7.

${ }^{79}$ OECDA, Interfutures, 'New elements and their policy implication in AIS', 16 May 1978.

${ }^{80}$ Kogune was an economist who wrote the report Changing value patterns and their impact on the economic structure, Tokyo: Tokyo University, 1982.

${ }^{81}$ OECDA, Interfutures, letter from Oshima to Lees, 24 December 1975; memorandum, 12 December 1979, signed by Oshima; 'Proposed financial contribution from a private foundation to the Interfutures project: note by the General secretary’, 24 May 1977, C (77) 89; Press release, 28 January 1976.

${ }^{82}$ OECDA, Interfutures, 'Proposed financial contribution from a private foundation to the Interfutures project: note by the secretary general', 24 May 1977, Annex A, 'Changing value patterns and their impact on the economic structure, a report to the Toyota Foundation', 8 January 1979.

${ }^{83}$ Michel Crozier, Le phénomène bureaucratique, Paris: Editions du Seuil, 1963. Crozier was also a member of the French Plan Group in 1985.

${ }^{84}$ Zbiegnew Brzezinski, Between two ages: America's role in the technetronic era, New York: Viking Press, 1970.

${ }^{85}$ OECDA, Interfutures, Chapter draft, 'National and international institutions', p. 17; Lesournes, Les mille sentiers, p. 18; Houghton Library, Harvard University, Bell Papers, Daniel Bell, 'The next twenty-five years'.
} 
In the final report of the Interfutures group, discussion of the NIEO and changes on world commodity markets was downplayed in favour of an analysis of the world monetary system after Bretton Woods, and chapters on the institutional structure and value changes in the West. These argued again that the main challenge to the future of the Western world lay in 'rigidities that reduced the possibility for future adjustment' as Western governments reacted to popular demands with extended forms of protection. Problems of ungovernability included the possibility that the welfare state might well have gone too far in some countries in terms of an extension of the 'non-market sector. ${ }^{86}$ With a scenario of moderate growth and continued pressures from the Third World, the 'redistribution of national income becomes a pressing concern'. Domestic causes of inflation had to be fought, and 'structural inadaptation to supply and demand' in unemployment dealt with. It was necessary to control bureaucracies and political systems against the pressures of competing claims, and governments had to attack the 'psychological basis of present problems'. 'If there is no active response from the AIS, they will react passively to these changes in their environment and this may affect significantly their potential for growth. ${ }^{87}$

The Trilateral Commission was, however, not the only influence on the Interfutures group. In 1975, at the same ministerial meeting that saw the creation of the Interfutures research project, the OECD appointed the McCracken group, with the particular purpose of studying the stagflation crisis and the underlying causes behind the erosion of growth and employment in the Western economies. The president of the group was the American economist William McCracken. ${ }^{88}$ The group came to the conclusion that instabilities in Western economies had rendered the macro economic models that had been used through the post-war era of Keynesian demand management inefficient. It therefore argued that economic planning had to be shifted from a previous emphasis on conjectural forecasts towards structural issues that should be dealt with through a new kind of qualitative analysis of 'long term trends and developments' ${ }^{89}$ The experimentation with scenarios in the Interfutures project was part of a double mandate shared between the groups in extending steering towards a more long-term perspective, and shifting planning from the focus on conjecture to 'trends'.

Both groups made direct links between endogenous structural problems and changes in the world situation driving inflationary movements. And both argued that the main trends driving up prices were value revolutions and 'unsatisfied aspirations' in the developing world as well as in the West. Fluctuations in commodity prices, raw materials, and currencies were seen as being based in irrational sentiments and psychological reactions in the developing world, adding to social tensions and irreconcilable expectations in the West. Rising prices were thus defined as 'a psychological problem which depends on expectations'. ${ }^{90}$

The McCracken group ascribed a new role to governments in terms of constructing positive images of the future that might wear down negative feelings, and influence 'creative and energetic people grasping opportunities'. Such positive images would increase the 'social willingness to accept the continuing adjustment of economic structures'. ${ }^{91}$ A highly similar statement came from one of the Interfutures consultants: 'if the advanced countries were in the long term to refute successfully the constantly reiterated demands of the Third World for a structural policy ... it had to be emphasised that the mere statement of the advantage of the free market system

\footnotetext{
${ }^{86}$ OECDA, Interfutures, 'National and international institutions'.

${ }^{87}$ OECDA, Interfutures, Draft outline of background paper to the meeting of senior officials, 5 February 1978; Main issues paper, September 1978.

${ }^{88}$ Schmelzer, Hegemony of growth, p. 317; Paul McCracken, et al., Towards full employment and price stability: a report to the OECD by a group of independent experts, Paris: OECD, 1977.

${ }^{89}$ OECDA, McCracken folders, letter from Emile Lennep to Paul McCracken, 15 April 1976.

${ }^{90} \mathrm{OECDA}$, McCracken folders, draft of the McCracken report by Assar Lindbeck, n.d.; Memorandum, second meeting of the McCracken group, 22-23 January 1976.

${ }^{91}$ OECDA, McCracken folders, McCracken report, 'The origins of the present problems'.
} 
was not sufficient, ... unless the OECD countries themselves refrained from suspending the market economy. ... the decisive factor would not simply involve the rejection of any proposal for world-wide bureaucratic planning, but rather the convincing presentation of a constructive, future-oriented alternative. ${ }^{92}$ From the interaction with the McCracken group, scenarios thus emerged as a method with yet another task, that of creating assertive and reassuring images of the future for Western and global populations alike. 'The more the OECD governments can lead the public to share a constructive vision of the future, the greater will be the ability of these governments to implement sets of consistent long term policies.' This 'positive message', Interfutures argued, would bring home the idea that possible physical limits in natural resources over the long term could be overcome by political, social, and institutional adaptation to market mechanisms. ${ }^{93}$

\section{Scenarios as the management of interdependence}

Retrospective discussions of the Interfutures project proposed that it was the linking of structural challenges in the Western world with a new world situation consisting of a multitude of new actors that was the key message of the 1978 report and the scenarios that it eventually proposed. ${ }^{94}$ These were: a scenario of continued high growth, recreating social harmony in the Western world and new export markets for Third World nations, but also an 'oligopolisation de la vie sociale par l'état'; a scenario in which low growth led to increased social turbulence in the Western world and further disgruntlement in the Third World; and a scenario in which there was open confrontation between the West and the Third World owing to protectionist stances in the former and further radicalization in the latter.

The choice of scenarios as the preferred method of Interfutures was in fact not a product of a critical evaluation of the determinism in world models, but a conspicuous choice that had to do with the appointment of Jacques Lesourne as director. At the end of his career, Lesourne became the editor of Le Monde, and used his editorial position to argue for the liberalization of French labour markets. He was a polytéchnicien, having studied in the École des Mines, which pioneered cost-benefit analysis and project planning within the French administration, and which was also central in introducing operations research and systems analysis in France - and, through networks of French planners and consultants, in the Coal and Steel Union and the emergent European Community. ${ }^{95}$ Lesourne began his career in the late 1950 s with a set of writings on the formalization of economics and conjectural research. ${ }^{96} \mathrm{He}$ also worked for EDF with forecasts and scenarios of energy supply. In 1958 he created the consultancy Société des Mathématiques Appliquées (SEMA). SEMA used the tools of systems analysis and operations research as a way of structuring trade relationships with the former French colonies in the Maghreb, Algeria and Morocco, and with Egypt. The speciality of SEMA was forecasting energy resources, beginning with carbon; overseeing industrialization processes; developing air, transport, and banking systems; and pioneering consumer preference surveys for French multinationals. In short, SEMA helped French companies manage their relationships with the newly independent nations. In 1975, the consultancy outsourced and created MITRA Iran, focused on the Persian oil market

\footnotetext{
${ }^{92}$ Michalski, 'OECD Interfutures project', p. 327.

${ }^{93}$ Facing the future, p. 195.

${ }^{94}$ Malkin and Sacco, 'Interfutures'.

${ }^{95}$ Particularly Louis Armand, Pierre Masse, and Jacques Delors.

${ }^{96}$ Lesourne wrote a series of books, including Technique économique et gestion industrielle, Paris: Dunod, 1958; Les systèmes de destin, Paris: Dalloz, 1976; Les mille sentiers: la fin des habitudes, Paris: Seghers, 1985; and L'économie de l'ordre et $d u$ désordre, Paris: Economica, 1991. The book of essays in Lesourne's honour includes statements on their former student by Kenneth Arrow, Robert Solow, and Hebert A. Simon, all arguing that Lesourne's perspective on the economy as an interdependent system was novel and original. See Thépot, et al., Décision, prospective, auto-organisation. See also Daniel Bell, 'Reflections at the end of an age', in ibid., pp. 361-7.
} 
(Anglo-Iranian Oil had been nationalized by the Mossadegh regime in 1951). ${ }^{97}$ From SEMA, Lesourne became director of Futuribles international, where he also began working with the Global Business Network, and in 1975 he was recruited to the OECD.

Lesourne can be linked to a particular intellectual environment known in France as 'prospective', which emerged as a form of management consultancy and strategy planning in the mid 1950s. It had origins in the French patronat, as management training for the directors of the large companies (including many that were clients of SEMA). Its purpose was to foster 'décision rationelle' (rational decision) in a large organization, faced with a multitude of decisions emanating from other actors in the corporate and world environment. ${ }^{98}$ In the late $1950 \mathrm{~s}$, this prospective environment was central in conducting French reflections on the emergence of a Third World. In fact it was conducive to the very notion of the Third World, which was first introduced in a set of writings by the French demographer Alfred Sauvy, who had contributed to reflections in the Cercle de prospective. There, decolonization led to interpretations of a phenomenon referred to as 'l'encombrement' (crowding). This 'crowding' depicted a form of chaos resulting from the arrival of new actors in an established system, and from the fact that these did not share the same image of the future as other actors. In other words, Sauvy's notion of the Third World had a direct connotation of the idea of a new world, which rejected the future images of the West. ${ }^{99}$

Prospective had similarities with the scenario tool as it was developed in the US by the nuclear strategist Herman Kahn. ${ }^{100}$ It shared with Kahn's scenario tool the notion of systems rationality, and the idea that inductive reasoning around plausible changes could replace facticity and quantitative reasoning as a way of delineating possible futures. ${ }^{101}$ It also shared with Kahn's scenario tool the idea of using scripted stories of the future as a way of outlining policy-relevant alternatives of action. To Lesourne, scenarios were an active policy tool, which enabled political decision-making to span the whole 'system', and anticipate the actions of other actors within this system. In other words, scenarios were a method for managing world relationships, by actively laying out a set of expectations on the future. ${ }^{102}$

In the main issues paper produced by Lesourne for a high-level meeting of senior officials at Château de la Muette in Paris in 1978, two dominant scenarios were proposed. Scenario one was a new growth scenario, in which the rigidities of Western nations were handled through a rapid adaptation of values and a 'conscious drive' towards new patterns of output and consumption. Scenario two was an enduring stagflation scenario, where prevailing conflicts about the distribution of national income rendered the Western world incapable of putting up a united front

\footnotetext{
${ }^{97}$ Manfred Polh, Handbook on the history of European banks, New York: Edward Elgar, 1994, p. 249. SEMA published a periodical on investments in Middle Eastern and African economies, Cahiers SEMA. See 'Le developpement internationale du groupe METRA', in PCM: Revue publiée par l'association professionnelle des ingénieurs des Ponts et Chaussées et des Mines. Les entreprises françaises à l'étranger, 10, 68, 1971, pp. 93-9; Stephane Cordobes and Philippe Durance, 'Entretiens de la mémoire de la prospective: Jacques Lesourne', Paris: CNAM, 2004. Michel Godet, Lesourne, and Crozier also contributed to the Institut Auguste Comte, whose mission was to educate managers of corporations and administration in 'solving complex problems'. See Timothy Mitchell, Carbon democracy: political power in the age of oil, Cambridge MA: Harvard University Press, 2011.

${ }^{98}$ See 1985: la France face au choc du futur, Paris: Commissariat Général au Plan, 1972, pp. 192-7. The report included Crozier and Bernard Cazes and many of the themes of the Interfutures group.

${ }^{99}$ Alfred Sauvy, Le tiers monde, Paris: Presses Universitaires de France, 1956; Prospective 3, 'Rapport de l'Occident avec le reste du monde', April 1959, pp. 11, 22.

${ }^{100}$ Sharon Ghamari Tabrizi, The worlds of Herman Kahn, Cambridge, MA: Harvard University Press, 2005.

${ }^{101} \mathrm{Kahn}$ worked directly with another French prospectiviste, a colleague to Lesourne in Futuribles International, Pierre Wack, who imported Kahn's corporate scenarios to Royal-Dutch Shell. Pierre Wack, 'Scenarios: uncharted waters ahead', Harvard Business Review, 63, 5, 1985, pp. 73-89; see also R. J. Williams, 'World futures', Critical Inquiry, 42, 2016, pp. 473546.

${ }^{102}$ OECDA, Interfutures, Jacques Lesourne, 'L'exercise Interfuturs'; Facing the future, pp. 4-5; OECDA, Interfutures, 'World models' and 'Scenarios of world development'.
} 
towards the Third World, and in which there was thus a systemic confrontation and clash. ${ }^{103}$ In order to push the situation from scenario two to scenario one, Interfutures emphasized the role of scenarios as a communicative tool, a way of setting out a positive message of the promised future of 'positive adaptation'. Scenarios, it was argued, provided a key method for educating both national policy-makers and their electorates about structural challenges and the need to address them through a coherent idea of the long term. 'Instead of the real danger of introducing rigidities in dealing with crisis, AIS have potentially enormous capabilities of influencing their futures if they develop forward looking activities and sustained efforts to influence the future in positive ways. ${ }^{, 104}$ Positive messages had an audience both in the Western world and on the global level. By creating positive images of the benefits of long-term integration in world markets through cooperation with the AIS, the protectionist stances of OPEC could be averted and the Third World effectively divided into those nations remaining in a basic needs approach, and those who aspired to a share in a growing world market by becoming eventual members of the AIS. As full members of an expanding global market, the latter could be expected to take an increased responsibility for the functioning of this, as well as for carrying the burdens of development'. It was therefore essential to create positive images of development that could be shared by populations in the West and strategic parts of the Third World alike, and to 'consolidate areas of common interest'. ${ }^{105}$

The scenarios were more than the representation of the future that the 'message' contained; they were also the tool with which the message could be created and diffused. Teams of consultants were established in the developing nations to gather information from each region, but also to spread the Interfutures message of interdependence as the necessity of a harmonious long-term strategy of common interest to 'elites in the developing world [who] do not care about our problems and have a totally different picture of their role'. Interfutures meetings were set up with these consultants, as well as with a target group of Western leaders who had to be convinced of the message. ${ }^{106}$

\section{Concluding remarks}

The strategy of communicating a positive message was both a failure and a success. Initial debates around the Interfutures message of the need to meet Third World demands with new notions of mutual interests and key efforts at structural adaptation at home led to grumbles from member states. As several authors have shown, the debate on adjustment policies, both within the OECD and in other organizations such as the European Community, did not signal a clear-cut change from Keynesianism to monetarism after the first oil shock; rather, both the McCracken and the Interfutures group should be seen as spaces where so-called structural challenges were debated and given preliminary interpretations. As Beroud demonstrates, structural adjustment policies were rejected by several member states until the advent of the second oil shock in 1979. ${ }^{107}$ As already argued, several member states were also critical of the OECD stance on the NIEO as it transpired through the Interfutures report, and favoured RIO. The Interfutures consultant Walter Michalski retrospectively also described a suspicion of the 'time horizon', on the part of the member states. ${ }^{108}$

\footnotetext{
${ }^{103}$ OECDA, Interfutures, Main issues paper for the meeting of senior officials, Paris, 2 February 1979.

${ }^{104}$ OECDA, Interfutures, Midterm meeting, Summary of conclusions.

${ }^{105}$ OECDA, Interfutures, 'The evolution of international relations'; Summary of conclusions of the 4th meeting of the steering committee, 20-21 October 1977.

${ }^{106}$ OECDA, Interfutures, Annex 1, to note 2, decision by the Council, 1977, on meeting to be held with senior civil servants to allow them to think about the long term.

${ }^{107}$ Beroud, 'Positive adjustments'; Gayon, 'L'OCDE au travail'; Laurent Warlouzet, Governing Europe in a globalizing world: neoliberalism and its alternatives following the 1973 oil crisis, London: Routledge, 2018.

${ }^{108}$ Michalski, 'OECD Interfutures project', p. 320.
} 
However, the reception of the Interfutures report changed in the years after 1978, coming to be seen as a landmark in the laying out of a new strategy of the Western world towards the developing South. According to this view, the report was read both as a rejection of the NIEO and as a counter-attempt to set out a liberal version of globalization, which itself reflected colonial hierarchies. ${ }^{109}$ To the OECD itself, the report was important in laying foundations, through its pioneering use of the scenario method, of a new strategy of 'concerted action' aimed at gathering the key European economies around positive adjustment policies from 1978 onwards. In addition, Interfutures contributed to the shift within the OECD approach to the Third World, which from 1978 became clearly that of promoting ideas of 'equal partners' in an expanding market economy. This, in turn, reflected the recommendation of the Interfutures report, namely that a Western strategy had to be based on the identification of common interests with those actors in the LDCs that could be drawn into an image of an expanding global market - in the process, of course, eroding the capacity of a united Third World actor. ${ }^{110}$ The Interfutures materials were used in the creation of the so-called North-South dialogue, which aimed at identifying such points of shared interest, and in 1978 the OECD held its first meeting with the OPEC development agency. In the years after the publication of the report, interdependence was increasingly a question of various forms of regional collaborations and partnerships, and divisions within the Third World and OPEC itself were also manifest.

This article has argued that the Interfutures group, a previously unstudied research committee of the OECD, was central to the drawing up of a Western strategy for managing globalization. This strategy, I further argue, was perhaps not neoliberal in the sense of the policies that emerged after the second oil shock and the elections of Reagan and Thatcher, but it was certainly protoneoliberal, in the sense that it contained a reflection on the necessity to address Third Worldism and environmentalism, both of which were key challenges to the idea of Western-led industrial growth, with a new and concerted strategy that emphasized a positive image of a future world market and that saw the future world as divided between those world actors who were willing to embrace this market and those who were not. Importantly, I also believe that previous studies on the road leading to neoliberalism from the late 1970s and early 1980s have neglected to see precisely this proto-history, during which not one but several visions of globalization existed and posed such an existential dilemma to the Western world that they had to be met. The linking up, in the Interfutures scenarios, of structural challenges within the Western world with those in the larger world 'system' is crucial to this history. It was through the understanding of a new competitive pressure arising from new actors in the world system that arguments for the cutbacks in welfare states and liberalization of labour markets that would see their breakthrough in the Western world in the years after 1979 could be prepared. In other words, both Third Worldism and environmentalism were key components in the understanding of structural challenges of the first half of the 1970s, and it was through the epistemological work of groups such as Interfutures that these challenges were also gradually squeezed out in favour of other interpretations of structural adaptation.

The scenario method plays a key role in this story, as an alternative to other visions of the need to plan the world system. Scenarios aimed instead at the management of world interdependence by the conjuring of an optimistic future image of the expanding world market, and as such were presented as an essential tool for dealing with a possibly chaotic world situation and achieving worldwide political and economic stability. In this respect, the history of (some forms of)

\footnotetext{
${ }^{109}$ Abdalla, et al., Images of the Arab future, p. 8.

${ }^{110}$ OECDA, Interfutures, Emile van Lennep speech, 1981, 'North-South mutual interests in greater reliance on markets'; Staffan Sohlman, address to symposium on the role of the OECD in the twenty-first century, Tokyo University, 20 October 1994, http://www.oecd.org/officialdocuments/publicdisplaydocumentpdf/?cote=SG/PRESS(94)69\&docLanguage = En (consulted 12 November 2018). Helmut Furer, The history of the official development assistance committee, Paris: OECD, 1994; Dustan Wai, ed., Interdependence in a world of unequals: African-Arab-OECD economic cooperation for development, Boulder, CO: Westview, 1982.
} 
futures research intersects neatly with the (proto)history of neoliberalism, and scenarios in particular should be considered as tools in a new emerging rationality of managing world relationships and as, essentially, a political technology of liberal world order. In the period after the publication of the Interfutures report, the use of scenarios in world organizations exploded. From the late 1970s onwards, scenarios were used not only by the OECD, but also by other transnational actors such as, most importantly, the World Economic Forum and Royal-Dutch Shell, whose scenarios in the mid 1980s were no longer concentrated on oil issues, but on a wide range of issues pertaining to world stability and instability. ${ }^{111}$

Jenny Andersson is CNRS research professor and Co-Director of the MaxPo Center for coping with instability in advanced market societies at Sciences Po. Her most recent work is The future of the world: futurology, futurists and the struggle for the Cold War imagination (Oxford University Press, 2018).

\footnotetext{
${ }^{111}$ Shell energy scenarios to 2050, New York: Shell International, 2008; Christina Garsten and Adrienne Sörbom, 'Risk, resilience and alternative futures: scenario-building at the World Economic Forum', unpublished paper for the 14th EASA Biennial Conference, Milan, 20-23 July 2016, available at http://su.diva-portal.org/smash/get/diva2:1056506/FULLTEXT01. pdf (consulted 12 November 2018).
}

Cite this article: Andersson, J. 2019. The future of the Western world: the OECD and the Interfutures project. Journal of Global History 14: 126-144, doi:10.1017/S1740022818000384 